International Journal of Child, Youth, and Family Studies (2014): 5(4.2) 808-825

\title{
WHEN MATTER IN THE CLASSROOM MATTERS: ENCOUNTERS WITH RACE IN PEDAGOGICAL CONVERSATIONS
}

\author{
Kathleen Kummen
}

\begin{abstract}
This article considers how mattering and meaning are mutually constituted in the production of knowledge (Barad, 2007). Drawing on a research project with first year early childhood education (ECE) students in a university setting, I argue that material-feminism, as understood through the work of Barad $(2007,2008)$, offers a lens through which pedagogical practices can be re-conceptualized as more than anthropocentric endeavours. The research project explores the processes that occurred when a group of ECE students and I engaged with and in pedagogical narrations over one academic term as we attempted to make visible and disrupt the hegemonic images we held of both children and childhood. In the doing of pedagogical narrations, artefacts were produced that were not merely representations of our collaborative thinking. Rather, the artefacts that emerged-in between the material, the discursive and the participants, were themselves agentic; they invited us to shift our gaze and our conversation, and thereby new meanings and realities were produced. I provide one example that discusses how the presence of the artefacts invited "race" into a conversation of childhood in a way that reverberated in our thinking, feeling, and being. The article concludes by considering the pedagogical implications for learning, for both children and those learning to work with children, when matter comes to matter in the classroom.
\end{abstract}

Keywords: early childhood education, material-feminism, pedagogical narrations, post-qualitative research

Kathleen Kummen, Ph.D. is the Coordinator for the Early Childhood Care and Education (ECCE) Program at Capilano University, 2055 Purcell Way, North Vancouver, British Columbia, Canada, V7J 3H5. Her research activities and interests include early childhood teacher education, pedagogical narrations and issues of social justice in the early years. E-mail: kkummen@capilanou.ca 
International Journal of Child, Youth, and Family Studies (2014): 5(4.2) 808-825

[S]ince each intra-action matters, since the possibilities for what the world may become call out in the pause that precedes each breath before a moment comes into being and the world is re-made again, because the becoming of the world is a deeply ethical matter. (Barad, 2007, p. 185)

This article explores how mattering and meaning are mutually constituted in the production of knowledge (Barad, 2007). Drawing on a research project with first year early childhood education (ECE) students, I argue that material-feminism, as understood through the work of Barad (2007, 2008, 2011, 2012), offers a lens through which pedagogical practices can be re-conceptualized as more than anthropocentric ${ }^{1}$ endeavours. Material-feminism asks us to understand learning as more than internal cognitive processes of the individual learner or cognitive processes arising from encounters with other humans. Rather, we are called to also consider the agentic force of the matter of learning, such as text, images, space, time, and so forth. With our attention drawn to learning as more than an anthropocentric phenomenon, we then have the ethical obligation to consider what knowledges and realities are produced in the encounters with humans, matter, non-human others, and discourses in our practices with children (Lenz Taguchi, 2010).

This article begins by introducing the reader to the research project and the practice of pedagogical narrations ${ }^{2}$. Then thinking with ${ }^{3}$ Barad $(2007,2008)$, I engage with the following analytical question: How did the material presence of the artefacts intra-act with ourselves, the texts, the images of children and childhood to make and unmake our understanding of children and childhood? The article concludes by considering the pedagogical implications for learning, for materials, children and those learning to work with children, when matter comes to matter in the classroom.

\section{A Practice of Disruption: The Narration of the Pedagogical Narrations}

The inquiry emerged from my curiosity as a teacher of ECE students, a curiosity that was initiated when students shared with me the anxieties and tensions they experienced in their encounters with young children during their practica. It was further provoked by reading the work of reconceptualizing early childhood education (RECE) scholars (e.g., Cannella, 1997; Cannella \& Viruru, 2004; Dahlberg, Moss, \& Pence, 1999, 2007; Lenz Taguchi, 2010; MacNaughton, 2003, 2005a; Pacini-Ketchabaw \& Nxumalo,

\footnotetext{
${ }^{1}$ Anthropocentric or humancentric is a belief in human supremacy whereby humans are positioned above all other matter both living and non-living. This position also places "the human subject viewing the world from a privileged and foundational point of view” (Hultman \& Lenz Taguchi, 2010. p. 526)

${ }^{2}$ In British Columbia, Canada, the provincial early learning framework adopted the term pedagogical narration. The term narration highlights the dialogical aspect of the practice of pedagogical narrations, while the use of the plural form narrations emphasizes the ongoing and multiple nature of the practice. See, for example, Hodgins (2012) and Hodgins, Kummen, Rose, and Thompson (2013).

3 I employ the term thinking with in the manner described by Jackson and Mazzei (2012). They suggest that this walking alongside a theory (more simply than drawing on or referencing a theory), is a way to think methodologically and philosophically which challenges "qualitative researchers to think with their data (or to use data to think with theory) in order to accomplish a reading of data that is both within and against interpretivism" (p. vi, emphasis in original).
} 
International Journal of Child, Youth, and Family Studies (2014): 5(4.2) 808-825

2010; Pacini-Ketchabaw \& Pence, 2005), who asserted that hegemonic discourses of children and childhood regulate ECE practice so that other - and perhaps more just ways of living with young children are silenced. As an instructor/researcher, I became interested in engaging with students around the practice of pedagogical narrations as an apparatus that could make visible and disrupt the taken-for-granted assumptions the students and I held around children and childhood.

This research project took place at a small urban teaching university where I am employed as an instructor in Early Childhood Care and Education (ECCE). The participants were 32 students enrolled in a first-year course that has been a part of my regular teaching assignment for the past five years. The course introduces students to early childhood education history and the philosophies that guide the practice of Early Childhood Care and Education. As well, the course asks students to begin to critically reflect upon the roles and responsibilities of the Early Childhood Educator in the reconceptualized framework of ECE. The research project was introduced to the students at the beginning of the term at the same time they were introduced to other course activities and assignments. Permission from the students to use the artefacts they had constructed as pedagogical narrations was requested after the course had finished and final grades were posted, in accordance with university procedures. In this way, consent for their participation in the research process was not requested because it was part of the course requirements. However, their consent was requested to use the data generated by the research process.

As research participants, the students shared commonalities and differences, both known and unknown. All but three students were in their first year of either the diploma or degree program and had not yet completed a practicum in ECCE; all 32 students selfidentified in their registration papers as female. Some students were of Aboriginal descent or heritage, some were born in Canada, some were permanent residents, some were new citizens of Canada, and some were international students. Students of nonAboriginal heritage generally, though not exclusively, identified as having a heritage from Asia, the Middle East, or Europe. In addition to English, the most common languages spoken in the classroom were Korean, Chinese, Mandarin, Farsi, Arabic, and Hindi. The group's diversity was critical to the study because the pedagogical practice of pedagogical narrations is predicated on individuals bringing to the group their different experiences, knowledge, and so forth in order to be able to engage in a collaborative learning process. For example, in describing pedagogical documentation (a process very similar to pedagogical narration), Olsson (2009) writes, "each child contributes to the process in his or her specific and absolutely singular ways, but the contribution is caught up in the group’s process” (p. 21).

In the third week of the 15-week term, the process of creating pedagogical narrations began by asking the students to bring their image of the child to the classroom in the form of drawings, photos, and texts. Each student showed their image to the other students in her group while the other students wrote down their thoughts, questions, and assumptions, focusing on what understanding of childhood was being portrayed by the image, what the image's origins were, and how the concepts of natural or normal 
childhood were understood (MacNaughton, 2005b). This process was repeated until each student had shown her image to her group. The forum then opened up to allow the group to share what they had written and engage "in acts of contesting, disrupting and negotiating meaning” (MacDonald \& Sánchez, 2010, p. 26). Here, students engaged in dialogue using the course readings ${ }^{4}$ to assist them in making visible the assumptions, values, and beliefs embedded in the images. The 20- to 30-minute discussion ended with the students being asked to share their thoughts as to how these images ask educators to perform particular pedagogical practices and inhibit other practices. By the start of the fourth week, one student per group was randomly assigned to transcribe the discussion and post the text online in the class Moodle site (an online bulletin board). As well, all students were required to post their image of a child within their Moodle discussion group with an accompanying four- to five-sentence description of how the image connected to the student's understanding of children or childhood. When the term concluded, I began re-viewing the students' pedagogical narrations, thinking with Barad's (2007) theory of agential realism. Within agential realism, Barad sees matter and the discursive as mutually constituted, whereby neither is privileged and neither exists in the absence of the other. Barad (2007) contends that, "matter is produced and productive, generated and generative. Matter is agentic, not a fixed essence or property of things" (p. 137). This article attends to my analysis of the agentic force of these initial artefacts, which became empirical material that formed the foundation for the content of the pedagogical narrations and existed as tools to guide the research project.

\section{Pedagogical Narrations: A Material-Discursive Apparatus}

I use the term pedagogical narrations to describe the practice the students and I engaged with. Central to my understanding of pedagogical narrations is Lenz Taguchi's work with the concept and practice of pedagogical documentation. Drawing on Barad's (2007) agential realism, Lenz Taguchi (2010) posits that pedagogical documentation is a material-discursive apparatus (written with a hyphen to assert their inseparability). Thinking with physicist Bohr, Barad (2007) writes that apparatuses are "the material conditions of possibility and impossibility of mattering” (p. 148). In extending Bohr's understanding of the term apparatus, Barad writes that apparatuses are more than laboratory tools that enable measurements and represent ideas; they are materialdiscursive practices that "produce differences that matter" (p. 146). Barad extends Foucault's (1971, 1972, 1980) concept of material-discursive practices and explains that an apparatus is itself a material-discursive practice that produces - rather than simply represents - meaning and knowledge, and the objects and subjects of such meanings and knowledge. In this way, Barad understands an apparatus as a material-discursive practice whereby it is not merely an object, but is part of the process of intra-active performativity.

Barad uses the term intra-action, not interaction. The latter refers to the encounter between two presumed discrete and pre-existing entities, while intra-activity implies that entities are not distinct and inseparable, but exist in an ongoing becoming in which

\footnotetext{
${ }^{4}$ Course readings were taken from two text books written by Glenda MacNaughton (2003, 2005a), as well as articles from scholars such as Lenz Taguchi (2010) and Dahlberg, Moss, and Pence (2007).
} 
International Journal of Child, Youth, and Family Studies (2014): 5(4.2) 808-825

entities do not precede each other but "emerge through their intra-action” (Barad, 2007, p. 33). In my analysis, thinking with Barad's notion of intra-action, I considered how material intra-actions among humans, text, and images make and unmake understandings of children and childhood.

Within an agentic realism perspective, Barad (2007) extends and challenges an anthropocentric understanding of agency, whereby "agency is cut loose from its traditional humanist orbit. Agency is not aligned with human intentionality or subjectivity” (p. 177). Agency, for Barad, “is a 'doing' or 'being' in its intra-activity. It is the enactment of iterative changes to particular practices" (p. 178, emphasis as in original). This understanding of agency is significant to this research project in that it allows me to attend to the agentic force of both matter and discourse circulating in the practice of pedagogical narrations. Lenz Taguchi (2010) asserts that the text, images, and photographs produced "put things in motion by means of its own agentic force and materiality. Thus new possibilities for intra-action with other matter and organism will emerge” (p. 64).

Inspired by Lenz Taguchi's work, I developed a research project to explore the potential of pedagogical narrations to act as an apparatus for/in/with the generation of new knowledge and the transformation of practices among a group of first-year students in an ECE course. To provoke our thinking as the students and I engaged with the practice of pedagogical narrations, I developed three working questions to guide our process:

1. How will the students and I come to understand disturbances to our images of children and childhood as we collectively engage in pedagogical practices that may displace the discourses of children and childhood we hold?

2. How will the students and I interpret and revise our thinking as we deconstruct the discourses that become visible in our collective learning?

3. How will the students and I construct and adjust our practices with children as we participate in these pedagogical practices in a collective learning process?

One of the course's main learning objectives was to consider how societal values and beliefs (e.g., gender, race, and culture) affect educational practice; this objective provided me with space to engage with/in my research questions as part of the regular course delivery. The students and I collaboratively engaged with theoretical readings and multiple images (e.g., metaphors, stories, photographs, drawings) of children and childhood to displace or unhinge our taken-for-granted notions of children and childhood. New questions and provocations emerged in response to the ideas, images, readings, and so forth that were part of our collective learning. These questions were often unexpected, and they disrupted our thinking in unanticipated ways.

\section{Inviting Barad into the Postsecondary Classroom: Emergent Implications}

I engaged in this inquiry in what St. Pierre and Jackson (2014), thinking with Deleuze and Guattari (1980/1987), refer to as post-coding analysis: a "non-technique and 
International Journal of Child, Youth, and Family Studies (2014): 5(4.2) 808-825

non-method that is always in a process of becoming as theories interlink, intensify, and increase territory” (p. 717). Employing a process articulated by Jackson and Mazzei (2012) as thinking with the theory, I read and revisited three chunks of data alongside theories from Barad. Barad's (2007) attention to the relationship between the discursive and the material extended my thinking about the agentic force of the matter of learning, such as text, images, space, time, and so forth. In particular, it extended my thinking about how the process of pedagogical narrations operated as an apparatus or tool for change. Further, agential realism allowed me to attend to learning as a collaborative process that involves encounters with other humans and the more than human ${ }^{5}$.

In this study, engaging with pedagogical narrations as a material-discursive practice and thinking with Barad prompted the following analytical question: How did the presence of the particular artefacts produced in the practice of pedagogical narrations intraact with us, the texts, and the images to make and unmake our shapings and coshapings of children and childhood?

\section{Reconfiguring/Repositioning Artefacts}

In a pedagogical context, when teachers and students are seen as the agentic force in the classroom, matter such as materials, books, images, and so forth are rendered as tools of humans (Lenz Taguchi, 2010, 2011). Challenging the anthropocentric lens shifts the gaze to how the matter of learning matters: how matter in an intra-active pedagogy produces new possibilities for learning and meaning making. When we see matter as mattering, the materials, books, and images that are included or excluded from the activity of learning matter. The learning conversations are entangled with the matter, and in their entangled relationship with humans, realities are created. In this way, agency is not simply understood as humans choosing to act or not act in a particular fashion. Rather, humans and non-humans are entangled in a relationship that is not divisible, but that relationship entails responsibility and is therefore political. As Barad (2007) writes, "the attribution and exclusion of agency - like the attributions and exclusions involved in the construction of the human - are a political issue” (p. 216). Different viewpoints, questions of rights, and priorities are mobilized depending on where agency is seen to be located. Barad argues that prior assumptions of what is and is not agentic have political consequences. Consider current debates on the state of the world's environment. An anthropocentric view that looks at how humans can make change to better care for the environment for the sake of all humankind champions different rights and perspectives than an ecocentric view (Leopold, 1949/1986) that focuses on a biotic as a whole in which human existence is not seen as distinct from the rest of the world. For example, the anthropocentric position would seek to protect water, not for the sake of water in a relationship with/in the world, but for its utility to humans. This example of the political consequences of the assignment of agency is no less relevant in the classroom. Thinking with Barad as I revisited the data allowed me to attend to how the matter in the classroom mattered; in particular, how race could have been silenced from the classroom had it not been for some matter.

\footnotetext{
5 The term more than human is used in this article to "refer broadly to all that exceeds the human, including non-human matter, relations, meanings and understandings” (Pacini-Ketchabaw \& Nxumalo, 2014, p. 132).
} 
International Journal of Child, Youth, and Family Studies (2014): 5(4.2) 808-825

The concept of race is controversial and contested, reflecting an entangled history of colonization, politics, evolutionary theory, white supremacy, economics, and so forth (Ahmed, 2007). I acknowledge that race is entangled in this present-day inquiry and that it shapes and reshapes our understanding of issues of whiteness, diversity, and so forth. For the purpose of this study, I relied on an understanding of race that emerges from the work of M'charek (2010) whereby "differences, such as race, sex or sexual differences, are neither stable nor given” (p. 318). M'charek, elaborating on Donna Haraway’s (1992) notion of diffraction and interference, and Annemarie Mol's (2002) concept of multiplicity, explains how specific histories and practices enact certain versions of bodies. She argues that objects and bodies do not have an essence but "rather they are enacted in specific practices as effects of interferences. Differences materialize in the form of relations between various interferences” (p. 318). Race, then, is more than body markers (such as phenotypes) and social constructions (such as racial terms that label skin colour). Race and how race is understood emerge with/in relationships with practices and technologies that attend to differences. For example, the camera lens in the hands of Kevin Carter (1993) produces a particular version of race, gender, and Africa in his photo showing a vulture stalking a young girl in the Sudan.

In revisiting the data with Barad, I am able to attend to how the artefacts produced within the practice of pedagogical narrations reconfigured my teaching agenda in a way that pushed the students and me into unforeseen conversations that, in turn, generated new understandings and meanings. In this way, pedagogical narrations enacted agentic cuts producing different phenomena as differential patterns of mattering (Barad, 2007, p. 140). That is, the intra-action that occurred with/in the texts, images, and humans with/in the practice of pedagogical narrations co-shaped different realities that emerged as classroom curriculum. Barad's (2007) concept of agentic cuts was made evident by the construction of a collage that evolved out of my desire to present to the whole class all the original images of children and childhood that the students brought to class early on. For reasons of efficiency, I decided to put all of the images of human children (both photos and drawings) into one collage and all the non-human images into another collage.

I sat with the collage for some time, gazing at the children's faces and bodies. I was somewhat disturbed by the collage, and yet I could not articulate the source of the disturbance. As I looked at the collage, in my mind I could see the view from the front of our classroom. From that position, I looked out at a classroom filled with 20 students who self-identified as students of colour and 12 who self-identified as white. As I juxtaposed the image of our class in my mind with the images in the collage, the overwhelming "whiteness" in the collage of children became evident. As I closely examined each photo, there were children who appeared to be non-white, yet there was an overwhelming "whiteness" that was visible. There were 23 images of children, and I could only discern three children who, from my perspective, were children of colour. (In rereading this statement, and thinking with the work of Pacini-Ketchabaw and Nxumalo [2010] and Nxumalo [2012], perhaps the overwhelming whiteness reflected a default position on my part due to my own whiteness). 
International Journal of Child, Youth, and Family Studies (2014): 5(4.2) 808-825

At about this time, I was travelling with a colleague to a conference in another country. Wanting to prepare for the next few classes, I took the collage and some course materials on the trip. Sitting on the plane, I showed the collage to my colleague. She too gazed at the bodies and faces of the children presented in the collage. We sat together on a plane filled with people like those people in the city we had just flown from, whose skin tones were a multitude of shades. As my colleague sat in a plane that reflected racial diversity, the collage spoke to her, reminding her as it did me of the relationship between childhood, whiteness, and normality. Our observation that images of "typical” children and childhoods exclude race is far from being scientifically relevant. Certainly the work of critical race scholars in education (see, for example, Ahmed, 2006, 2009; Applebaum, 2006, 2012; Picower, 2009) provides ample indication that racism is normalized in education so that white privilege/supremacy is dominant. The work of these scholars contains copious assertions that white is the standard of normality from which all people are judged. Yet, as I sit here rereading the data with Barad, what appears important to me is that race became visible through the practice of pedagogical narrations. Barad (2012, as cited in an interview in Juelskær \& Schwennesen, 2012) speaks of "performing the labour of tracing the entanglements, of making connections visible, you're making our obligations and debts visible, as part of what it might mean to reconfigure relations of spacetimemattering” ${ }^{6}$ (p. 20).

As an apparatus of meaning making (Barad, 2007), pedagogical narrations became entangled with/in me, the students, and spacetimematterings to produce a collage - an artefact. This artefact itself then had an effect: Its presence unexpectedly invited a conversation about race where, without its presence, race had been silenced. The class focus was to consider how post-structural theory could help us reconceptualize our understandings of children, childhood, and early childhood education. With Foucault haunting me and with Guba and Lincoln (2005) reminding me of the issues of trustworthiness and authenticity in qualitative research, I have to confess to the reader that race, racialization, and whiteness were not concepts I had planned to focus on in my 13 weeks of instruction as I raced against the time constraints to meet the learning outcomes of the course. Yet, the collage entered into the classroom and its power to disturb me disrupted my agenda. I reassigned the readings for the next few weeks, asking the students to read a chapter by Glenda MacNaughton (2005b) looking at her notion of seeking "the otherwise". I was curious how the students would respond when they revisited the images after they had read and thought about MacNaughton's question, "What is your relation with whiteness?" (p. 187). Would we/they invite race and colour into the discussion? Would the whiteness of the images call out to them?

As for my colleague, I cannot help but wonder if or how the presence of diversity (the people with us on the plane) spoke in unity with the exclusion of diversity (in the collage) in that moment. Was she as startled as I was by the contrast of the physical presence of a diverse world and the seeming homogeneity resonating from the collage? Did her own research, readings, and history become entangled with the collage, causing race to call out to her? When I revisited these images, how did my history with skin

\footnotetext{
${ }^{6}$ Barad (2011) uses the term spacetimemattering to underscore how space, time, and matter are "mutually constituted through the dynamics of iterative intra-activity” (p. 12)
} 
International Journal of Child, Youth, and Family Studies (2014): 5(4.2) 808-825

colour and my unquestioned use of the term race become entangled with the images? Was I fixated on phenotypes, categorizing and classifying people on the basis of skin tone? Did I assume that diversity was merely the presence of non-white faces (Ahmed, 2009)? A curious assumption on my part, given that my sister's skin tone identifies her to many people as Aboriginal, while my skin tone identifies me as European. These questions will never be answered, nor is this an attempt to represent that moment in order to name the truth of it. What matters is that the artefact produced in the materialdiscursive practice of pedagogical narrations mattered. Lenz Taguchi (2010) refers to this as intra-pedagogy whereby the interaction and relationships between students and teachers is "inclusive of the performative agency of the material in the intra-actions of learning events” (p. 65). She asserts that, most often, pedagogy is assumed to be an individual cognitive process or something that happens in a relationship where at least one person has something to teach the other(s). This view of learning does not account for the entanglements that learning and teaching humans have with things, materials, furnishings, artefacts, and environments within an entanglement of spaces and time (Barad, 2007; Lenz Taguchi, 2010). Thinking with this notion of material as having an agentic force allows attention to be drawn to the collage in its intra-action with me, my colleague, and, of course, the students.

\section{The refiguring/repositioning continued}

The following week the collage entered the classroom with me as a slide that was projected onto the wall at the front of the classroom. As I mentioned previously, I had switched the assigned readings and the students were now reading a chapter by Glenda MacNaughton (2005b) looking at her notion of seeking "the otherwise”. At the beginning of the class, I asked the students to reflect on the collage, thinking with the ideas they had read in the chapter. My field notes reveal that the whiteness of the images remained silent. The students commented that the images reflected childhoods void of disability, illness, poverty, and unhappiness. Yet, the work of Ahmed (2006, 2007, 2009) and other critical race theorists reminds us that the silence of whiteness indicates the collective discrimination of those who are identified as non-white others. Or perhaps, as Picower (2009) suggests, the students had been schooled to know that to bring up race was taboo. I then read to them excerpts from MacNaughton's (2005b) chapter in which a young girl of Vietnamese heritage chooses a white doll as the doll that most looked like her from a group of dolls that were racially diverse. I concluded by reading with the various interpretations of this scenario by early childhood professionals who identified as white and those who did not identify as white. The room became quiet, and the large group discussion that usually ensued after the lecture part of the class stalled. MacNaughton's text became entangled in our thinking, joining in with the images, the previous readings, our own histories, and so forth. Another agential cut was made, repositioning our gaze and our thinking, and therefore reconfiguring our world. The addition of MacNaughton's text repositioned the entanglement; human speech was stalled. To support further conversation, I asked the students to get into their small working groups to consider MacNaughton's (2005b) question, "What is your relation with whiteness?” (p. 187). 
International Journal of Child, Youth, and Family Studies (2014): 5(4.2) 808-825

My field notes reflect my wandering around between the groups as they shared their responses to the collage. Some of the students wondered if the reason that so many of the images were white could be attributed to the Google search engine privileging images of white children. Others contemplated whether race was really important when considering childhood as a concept. Perhaps the prevalence of white children in the images was not as important as issues such as disability and social class. The text and images were pushing us to attempt to rework race in our classroom, and we resisted by pushing back with our use of / being with race. Our words re-enacted the text we had read about the child and the doll. The students also wondered if there were reasons other than race for the child to choose that particular doll. I moved through the groups, listening and joining in to their conversations. In each of the groups, I asked them to look at the collage and consider whether this was the only image of children in our classroom. What message would the poster relay to people entering our classroom? What would the collage tell people about our relationship with whiteness?

As I later revisited the students' narratives as artefacts that were part of the practice of pedagogical narrations, I could feel the disturbance of the collage as it reverberated in our thinking, feelings, and being. Sitting on colonized land, with students whose ancestors were the colonized and/or the colonizer, with students whose families had been subject to head taxes and internment camps within our province, the artefacts created turmoil in our thinking. Group F confessed to a past omission of race as they wrote: "As we look back at the majority of our images we now understand that there are specific equity issues. With the majority of images being Caucasian white middle class children, is this what we believe is our 'perfect childhood'?” Following the collage and the reading, the recorder for Group A (all names used in this article are pseudonyms) shared the following childhood memory:

As an Asian Canadian, I understand that race plays a big part in life. I grew up in Canada and all my beliefs and values are similar to a white Canadian's. Even at home my mom would always joke around saying how I am just like a banana, yellow on the outside and white on the inside. When I was younger I did not understand why people like to group different racial groups by colours. Until that one time in elementary school, I was practicing my writing on the chalkboard during break, a girl classmate came up to me and said, "You don't know how to write in English, you don't belong here, go back to China!" I was really upset about her comment but I didn't know why. At that very moment I wanted to be like her, a white Canadian. Now looking back at that situation my story is very similar to Kim's story. I wanted to change myself to fit in, and no child should want to change itself to fit in. (Yi-Min, Group B, 2011)

These texts and the other narratives then joined the collage as artefacts to revisit, coming out at other times to haunt us, to challenge us to re-image notions of race. Race continued to be present in our classroom through the new images and new narratives that entered, and through the students' re-remembering of childhood experiences that spoke of new understandings and meanings. The notions of diversity and inclusion moved beyond 
International Journal of Child, Youth, and Family Studies (2014): 5(4.2) 808-825

issues of developmental differences (for example, diverse learning styles and including children with disabilities) to include issues of race, colonization, and white privilege.

\section{(Re)Encounters with race: New complexities and tensions}

The collage became part of each group's collection of artefacts, brought out for small group discussions and occasionally being displayed on the wall as part of the lectures. As mentioned, Group A's narrative also became a tangible piece of matter in our classroom. We had begun to consider race as something that mattered as thoughts and realties were being reconfigured and repositioned. Barad (2007) writes that, "it is through specific agential intra-actions that the boundaries and properties of the components of phenomena become determinate and that particular concepts (that is, particular material articulations of the world) become meaningful" (p. 139). In this way, race did not enter into the curriculum as a result of human agency alone; it entered through a complex set of intra-actions that rearticulated race as something that mattered. Stewart (2010) eloquently expresses this notion of agency in the following:

Everything depends on the dense entanglement of affect, attention, the sense, and matter. This is not exactly intended or unintended, not the kind of pure agency we imagine marching forward ... but a balling up and unraveling of states of attending to what might be happening. It's an attunement to possibilities opening up and not necessarily good ones. But, maybe. (p. 6)

For example, Group E wrote, "We are more and more talking about race”. Petra and Misty echoed this observation as they explained that the collage, the readings, and their discussions had provoked them to attend to race and to celebrate difference as they went into childcare centres. Misty recalled how race lived in the centre in which she was observing as she shared a moment with a child that confirmed her "new understanding that children attended to race”. She wrote:

In my centre, there is a girl Lynn who has Chinese parents. When I met her at the first time, she asked me "Are you a Chinese girl?" I replied that "I'm a Japanese girl”. (Misty, Group E, 2011)

I do not mean to suggest that such conversations had not occurred previously, but rather the students felt that they were now significant enough to be documented. They mattered. In their mattering, these conversations invited new thoughts, ideas, images, and matter race - into the entanglement that was pushing and shaping the classroom curriculum into unforeseen places.

With our excitement about welcoming race into the conversation came new anxieties and unforeseen challenges. Now that we were talking about race, the racial assumptions, values, and beliefs we brought to our work with children and families began to emerge. Group E captured this new fear. "How do we work with race?" they asked of the class and themselves. "How do we avoid assumptions when they are everywhere? 
International Journal of Child, Youth, and Family Studies (2014): 5(4.2) 808-825

Can we think about children without thinking 'race'? Can we look at children without thinking of their colour? Can we interact with children without thinking about their background?" Their words came to class as artefacts for all of us to read and think with. We turned to MacNaughton's (2005a, 2005b) writing about Foucault's ideas to consider how truth, power, and knowledge are connected. MacNaughton's words, text, and stories became part of the larger material arrangement with/in our classroom. Her work became intertwined in the ongoing material-discursive practice of pedagogical narrations in our classroom, enacting an agential cut to produce the space for questions of politics, inequity, and racism. It would seem that in the doing of the pedagogical narrations as a material-discursive practice, we began to engage in micro-political acts that created an opening for different ways of being in the world with race and education.

Barad (2007) elaborated on Bohr's notion of apparatus by asserting that "apparatuses are the material conditions of possibility and impossibility of mattering: they enact what matters and what is excluded from mattering” (p. 148, emphasis in original). The pedagogical narrations were an apparatus in our classroom, enacting agential cuts and materializing different phenomena. New images of children entered the classroom through the students' revised images in the pedagogical narrations. These images now included children of colour.

Looking at the data and thinking with Barad, I was drawn now to nine of the revised images of children. Five images showed young children of colour in places far removed from our classroom: city streets, working in mines, hauling bricks, and carrying semi-automatic rifles. Four of the photos showed the smiling faces of a group of children reflective of many races and cultures. Thinking with the text we had been reading in class that focused on "othering 7 " and race, I placed a poster for Disney's It's A Small World that was part of one student's revised image beside the face of child carrying a semiautomatic rifle from another student's revised image.

Revisiting the data in this way and following Barad's understanding of agency, I was able to appreciate how another unexpected repositioning and reshaping occurred as the artefacts of our pedagogical narrations engaged with us and we engaged with them. Returning to the data, these nine images of children drew my attention back to the ideas, tensions, and questions that emerged as we engaged with them and other artefacts that were part of our practice with pedagogical narrations. It would appear that we struggled with how to represent the notion of race in childhood. In particular, four of the nine photos presented one of the dichotomies we faced as race entered our thinking of childhood. Those four images, showing smiling children holding hands encircling globes, reflected a celebration of multiculturalism whereby the similarities of all children erased any differences caused by culture and race, while the other five photos in the group of nine seemed to resonate a "single story of tragedy" (Adichie, 2009). Adichie refers to the notion of a single story of tragedy to describe the tendency of the media to focus on

\footnotetext{
${ }^{7}$ The term "othering" is used to refer to the conscious or unconscious action of delegating another person or group of people as being different or apart from oneself. The text that we were reading by MacNaughton (2005a) uses the term to discuss racial inequities in the early childhood classroom.
} 
International Journal of Child, Youth, and Family Studies (2014): 5(4.2) 808-825

issues of famine, war, or genocide when describing the countries of the African continent, excluding the possibility that there could also be stories of joy and triumph.

Barad's notion of agency helped me to attend to the conflict that these images created in our thinking. On one hand, we talked about the importance of classrooms that promote issues of equity and celebrate differences. My course notes reflect our conversations as we considered how writers such as Derman-Sparks (1989) warned that multiculturalism as "an event" can maintain other cultures as exotic ${ }^{8}$. We considered with Burman (2008) our position in the world, and with MacNaughton (2005a, 2005b) we struggled with our relationship with whiteness, yet we were drawn back to single stories of tragedy as being somehow embedded in race. This tension was raised as I became aware that while the majority of students self-identified as non-white, when asked to select images of children that reflected diversity, they mainly selected photographs of children of colour living in extreme conditions of poverty. The majority of photographs that were brought to class to reflect diversity showed, for example, children of colour in ragged clothes working in terrible conditions or carrying weapons of war. There were no photographs of white children living a story of tragedy.

Our thoughts and ideas were recorded and became artefacts to be revisited in our classroom and on Moodle. Further agential cuts were made, shifting and repositioning us in the world with race, children, and education so that the multiple (and perhaps even new) realities that were being enacted in the event were made visible.

\section{An Ethical Obligation: Attending to the Matter that Matters in Post-secondary Classrooms}

Material feminism asks us to understand learning as more than a cognitive process that occurs within an individual; Lenz Taguchi (2010) explains that it is instead

the phenomena that are produced in the intra-activity taking place in between the [learner], its body, its discursive inscriptions, the discursive conditions in the space of learning, the material available, the time-spacerelations in a specific room of situation organisms, where people are only one such material organism among others. (p. 35)

With our attention thus drawn to learning as more than an anthropocentric phenomenon, Lenz Taguchi asserts that we then have an ethical obligation to consider what knowledges and realities are produced in the encounters that occur among humans, matter, and discourses in our practices with children.

This research project begins to examine the implications of attending to the matter of intra-active learning in the education of early childhood educators. As noted previously, artefacts emerged in-between and among the material, the discursive, and the participants, and were themselves agentic. They called out to us, drawing our gaze and our discussions, so that new meanings and realities were produced. The collage described

\footnotetext{
${ }^{8}$ Derman-Sparks (1989) promotes the notion of an anti-bias curriculum, whereby culture is not seen only in a yearly celebration of difference in which the unique differences between cultures are put on display.
} 
International Journal of Child, Youth, and Family Studies (2014): 5(4.2) 808-825

was a material document and, as Prior (2003) reminds us, documents do something. Within this study, tangible objects spoke to the students and me and invited us into political action with their presence, thereby creating a political space for discussions (Berger, 2010), in this case to attend to the material aspects of race.

This study invited educators of ECE student teachers to attend to the matter that is in classrooms in which the students are engaged in learning how to be early childhood educators. As Haraway (2011) contends, "it matters what matter we use to think other matters with; it matters what stories we tell to tell other stories with; it matters what knots knot knots, what thoughts think thoughts, what ties tie ties” (p. 4). Further studies are needed to examine what matter matters in the education of early childhood educators. What is included and excluded in the storying of early childhood education? For example, in the history of ECE in Canada, are stories of residential schools as visible as stories of Froebel's first kindergartens? Do stories of school readiness include stories of colonization? Whose faces grace the covers of textbooks? As Barad (2007) writes, "the attribution and exclusion of agency - like the attributions and exclusions in the construction of the human - are political issues” (p. 216).

The purpose of this study was to disrupt the students' thinking and my own, though I would argue that this disruption was not a process of capturing or representing our thinking so that we could engage in the act of self-critique. I am indebted to Karen Barad's assertion that critique alone is not helpful in beginning conversations that might welcome collaborative engagement with new possibilities and opportunities. Barad's declaration, in a 2012 interview with Juelskær and Schwennesen, that she is interested in building relationships with "scientists of good will, scientists who care deeply about using science for the purpose of mutual flourishing” (p. 14) strongly resonates with my intention in building relationships with students in early childhood education. In speaking about her work with students learning to engage in the sciences, Barad (as cited in Juelskær \& Schwennesen, 2012,) notes that the students have an interest in issues of social justice within science and that what is needed in their education "is a deep appreciation of the entanglements of facts and values (p. 15)”. In my work with students in early childhood education, I have found that they, too, are deeply committed to issues of social equity and justice. Thinking with Barad throughout this journey, I believe that what is needed in the education of future early childhood educators is a curriculum that attends to "how values matter and get materialized, and the interconnectedness of ethics, ontology, and epistemology” (Barad, 2012, as cited in Juelskær \& Schwennesen, 2012, p. 15). When the matter of learning matters, students and instructors are decentred as the focal point of cognitive process. Rather, they are considered to exist in relationship with/in the texts, images, materials and the other more than human forces that intra-act in an ever-emerging world. 
International Journal of Child, Youth, and Family Studies (2014): 5(4.2) 808-825

\section{References}

Adichie, C. (2009). The danger of a single story. Transcript. Retrieved from: http://ssw.unc.edu/files/TheDangerofaSingleStoryTranscript.pdf

Ahmed, S. (2006). The nonperformativity of antiracism. Meridians, 7(1), 104-126. Retrieved from: http://www.jstor.org/stable/40338719

Ahmed, S. (2007). Multiculturalism and the promise of happiness. New Formations, 63, 121-137. Retrieved from: http://www.lwbooks.co.uk/journals/newformations/contents.html

Ahmed, S. (2009). Embodying diversity: Problems and paradoxes for black feminists. Race Ethnicity and Education, 12(1), 41-52. doi: 10.1080/13613320802650931

Applebaum, B. (2006). Race ignore-ance, color talk, and white complicity: White is...white isn't. Educational Theory, 56(3), 346-362. doi: 10.1111/j.17415446.2006.00230.x

Applebaum, B. (2012). Reframing responsibility in the social justice classroom. Race, Ethnicity and Education, 15(5), 615-631. doi: org/10.1080/13613324.2012.674028

Barad, K. (2007). Meeting the universe halfway: Quantum physics and the entanglement of matter and meaning. Durham, NC: Duke University Press. http://dx.doi.org/10.1215/9780822388128

Barad, K. (2008). Posthumanist performativity: Toward an understanding of how matter comes to matter. In S. Alaimo \& S. Hekman (Eds.), Material feminisms (pp. 120 154). Bloomington, IN: Indiana University Press.

Barad, K. (2011). Nature's queer performativity. Critical Humanities and Social Sciences, 19(2), 121-158. doi: 0.1353/qui.2011.0002

Barad, K. (2012). On touching - The inhuman that therefore I am. Journal of Feminist Cultural Studies, 25(5), 206-223. doi:10.1215/10407391-1892945

Berger, I. (2010). Extending the notion of pedagogical narration through Hannah Arendt's political thought. In V. Pacini-Ketchabaw (Ed.), Flows, rhythms, and intensities of early childhood education curriculum (pp. 57-76). New York: Peter Lang.

Burman, E. (2008). Deconstructing developmental psychology (2nd ed.). London: Routledge. http://dx.doi.org/10.4324/9780203946169

Cannella, G. (1997). Deconstructing early childhood education: Social justice and revolution. New York: Peter Lang. 
International Journal of Child, Youth, and Family Studies (2014): 5(4.2) 808-825

Cannella, G., \& Viruru, R. (2004). Childhood and postcolonization: Power, education, and contemporary practice. New York: RoutledgeFalmer.

Carter, K. (1993). Struggling Girl, Sudan. Retrieved from http://paulagortazar.blogspot.ca/p/ethical-limits-in-documentary.html

Dahlberg, G., Moss, P., \& Pence, A. (1999). Beyond quality in early childhood education and care: Postmodern perspectives. London: Falmer Press.

Dahlberg, G., Moss, P., \& Pence, A. (2007). Beyond quality in early childhood care and education: Postmodern perspectives (2nd ed.). London: Routledge.

Deleuze, G., \& Guattari, F. (1987). A thousand plateaus: Capitalism and schizophrenia (H. Tomilson \& R. Galeta, Trans.). Minneapolis: University of Minnesota Press. (Original work published 1980)

Derman-Sparks, L. (1989). Anti-bias curriculum: Tools for empowering young children. Washington, DC: National Association for the Young Children.

Foucault, M. (1971). Orders of discourse. Social Science Information, 10(2), 7-30. doi: $10.1177 / 053901847101000201$

Foucault, M. (1972). The archaeology of knowledge. London: Tavistock.

Foucault, M. (1980). Power/knowledge: Selected interviews and other writings 19721977. New York: Pantheon.

Guba, E., \& Lincoln, Y. (2005). Paradigmatic controversies, contradictions, and emerging confluences. In N. Denzin \& Y. Lincoln (Eds.), The SAGE handbook of qualitative research (3rd ed., pp. 191-216). Thousand Oaks, CA: SAGE.

Haraway, D. (2011). SF: Science fiction, speculative fabulation, string figures, so far. Paper presented at the Science Fiction Research Association annual meeting, July 2011, Lubin, Poland.

Haraway, D. (1992). Promises of monsters: A regenerative politics for inappropriate/d others. In L. Grossberg, C. Nelson, \& P. Treichler (Eds.), Cultural studies (pp. 295-337). London: Routledge.

Hodgins, B. D. (2012). Pedagogical narrations’ potentiality as a methodology for child studies research. Canadian Children, 37(1), 4-11. 
International Journal of Child, Youth, and Family Studies (2014): 5(4.2) 808-825

Hodgins, B. D., Kummen, K., Rose, S., \& Thompson, D. (2013). Narrations as a methodology for qualitative educational research: Challenging multiple poverties. Paper presented at the American Educational Research Association annual meeting, April 2013, San Francisco, CA.

Hultman, K., \& Lenz Taguchi, H. (2010). Challenging anthropocentric analysis of visual data: A relational materialist methodological approach to educational research. International Journal of Qualitative Studies in Education, 23(5), 523-542. doi: 10.1080/09518398.2010.500628

Jackson, A. Y., \& Mazzei, L. A. (2012). Thinking with theory in qualitative research: Viewing data across multiple perspectives. New York: Routledge.

Juelskær, M., \& Schwennesen, N. (2012). Intra-active entanglements - An interview with Karen Barad. Kvinder, Køn \& Forskning, 1-2, 10-23. Retrieved from: http://koensforskning.soc.ku.dk/kkf/forsidebokse/nyeste/Interview_Karen_Barad. pdf/

Lenz Taguchi, H. (2010). Going beyond the theory/practice divide in early childhood education: Introducing an intra-active pedagogy. New York: Routledge.

Lenz Taguchi, H. (2011). Investigating learning, participation and becoming in early childhood practices with a relational materialist approach. Global Studies of Childhood, 1(1), 36-50. Retrieved from http://dx.doi.org/10.2304/gsch.2011.1.1.36

Leopold, A. (1949/1986). A sand county almanac. New York: Ballentyne/Random House.

MacDonald, M., \& Sánchez, A. (2010). Provoking dialogue: Promote a deeper understanding of teaching and learning through images and documents. Canadian Children, 35(2), 25-30.

MacNaughton, G. (2003). Shaping early childhood: Learner, curriculum and contexts. Berkshire, UK: Open University Press.

MacNaughton, G. (2005a). Doing Foucault in early childhood studies: Applying poststructural ideas. London: Routledge. http://dx.doi.org/10.4324/9780203465332

MacNaughton, G. (2005b). Seeking the "otherwise": Re-meeting relations of "race” in early childhood classroom histories. In G. MacNaughton, Doing Foucault in early childhood studies: Applying poststructural ideas (pp. 110-140). London: Routledge.

M'charek, A., (2010). Fragile differences, relational effects: Stories about the materiality of race and sex. European Journal of Women's Studies, 17(4), 307-322. doi: $10.1177 / 1350506810377698$ 
International Journal of Child, Youth, and Family Studies (2014): 5(4.2) 808-825

Mol, A., (2002). The body multiple: Ontology in medical practice. Durham, NC: Duke University Press

Nxumalo, F. (2012). Unsettling representational practices: Inhabiting relational becomings in early childhood education. Child \& Youth Services, 33(3-4), 281302. doi. 10.1080/0145935X.2012.745783

Olsson, L. (2009). Movement and experimentation in young children's learning: Deleuze and Guattari in early childhood education. London: Routledge.

Pacini-Ketchabaw, V., with Nxumalo, F. (2010). A curriculum for social change: Experimenting with politics of action or imperceptibility. In V. Pacini-Ketchabaw (Ed.), Flows, rhythms, and intensities of early childhood education curriculum (pp. 133-154). New York: Peter Lang.

Pacini-Ketchabaw, V., \& Nxumalo, F. (2014). Posthumanist imaginaries for decolonizing early childhood praxis. In M. Bloch, B. Swadener, \& G. Cannella (Eds.), Reconceptualizing early childhood care and education: A reader (pp. 131-142). New York: Peter Lang.

Pacini-Ketchabaw, V., \& Pence, A. (2005). The reconceptualizing movement in Canadian early childhood education, care, and development. In A. Pence \& V. Pacini-Ketchabaw (Eds.), Canadian early childhood education: Broadening and deepening discussion of quality (pp. 5-20). Ottawa, ON: Canadian Child Care Federation.

Picower, B. (2009). The unexamined whiteness of teaching: How white teachers maintain and enact dominant racial ideologies. Race, Ethnicity, and Education, 12(2), 197215. Retrieved from http://dx.doi.org/10.1080/13613320902995475

Prior, L. (2003). Using documents in social research. Thousand Oaks, CA: SAGE. http://dx.doi.org/10.4135/9780857020222

St. Pierre, E. A., \& Jackson, A. Y. (2014). Qualitative data analysis after coding. Qualitative Inquiry, 20(6), 715-719. doi: 10.117/1077800414532435

Stewart, K. (2010). Atmospheric attunements. Rubric: Writing from UNSW, 1(1), 1-14. Retrieved from http://rubric.org.au/wp-content/uploads/2010/05/AtmosphericAttunements.pdf 